\title{
DDB1 wt Allele
}

National Cancer Institute

\section{Source}

National Cancer Institute. DDB1 wt Allele. NCI Thesaurus. Code C93073.

Human DDB1 wild-type allele is located within 11q12-q13 and is approximately $34 \mathrm{~kb}$ in length. This allele, which encodes DNA damage-binding protein 1, plays a role in the mediation of repair to DNA damaged by ultraviolet radiation and the regulation of protein ubiquitination. 